http://dx.doi.org/10.18778/1643-0700.20.06

\author{
Paulina SAPIŃSKA*
}

\title{
DOSTĘPNOŚĆ DO WYBRANYCH INSTYTUCJI KULTURY W POWIECIE ZDUŃSKOWOLSKIM
}

\begin{abstract}
Streszczenie. W artykule dokonano oceny dostępności pieszej, rowerowej i samochodowej do 29 instytucji kultury w powiecie zduńskowolskim. W wyniku przeprowadzonych badań przedstawiono liczbę osób mieszkających w domach jednorodzinnych i budynkach wielorodzinnych w obrębie izochron: do 5 minut, od 5 do 10 minut oraz od 10 do 15 minut od placówek kulturalnych. W tym celu wykorzystano dane z zasobów OpenStreetMap i z Banku Danych Lokalnych oraz usługę sieciową WMS, prezentującą aktualną Bazę Danych Obiektów Topograficznych. Przeprowadzone analizy wskazują, że najlepszą dostępnością charakteryzują się biblioteki, a najgorszą muzea. Zróżnicowanie dostępności mieszkańców analizowanego powiatu do ośrodków kultury, muzeów i bibliotek wynika z liczby i położenia poszczególnych placówek kultury oraz z rozmieszczenia zabudowy mieszkaniowej jedno- i wielorodzinnej. Najlepszy dostęp do instytucji kultury mają mieszkańcy Zduńskiej Woli, gdzie występują największe skupiska zabudowy mieszkaniowej wielorodzinnej oraz najgęstsza sieć dróg w powiecie.
\end{abstract}

Słowa kluczowe: kultura, muzea, biblioteki, powiat zduńskowolski, dostępność transportowa

\section{WPROWADZENIE}

Podstawy dla organizowania działalności kulturalnej przez władze centralne i samorządowe w Polsce określa konstytucja, według której Rzeczpospolita Polska stwarza warunki upowszechniania i równego dostępu do dóbr kultury, będącej

* Paulina Sapińska, mgr, Uniwersytet Łódzki, Wydział Nauk Geograficznych i Wydział Zarządzania, e-mail: paulina95sapinska@gmail.com. 
źródlem tożsamości narodu polskiego, jego trwania i rozwoju ${ }^{1}$. Działalność kulturalna (zgodnie z „Ustawą z dnia 25 października 1991 r. o organizowaniu i prowadzeniu działalności kulturalnej") polega na tworzeniu, upowszechnianiu i ochronie kultury ${ }^{2}$. Ochrona związana jest ze sprawowaniem opieki nad zabytkami i pozostałymi dobrami kultury. Upowszechnianie można rozumieć jako podejmowanie czynności mających na celu zainteresowanie kulturą. Ma to związek z jej promowaniem i udostępnianiem, co odbywa się poprzez przygotowywanie oferty skierowanej do rozmaitych grup odbiorców. Natomiast tworzenie kultury to inaczej przyczynianie się do powstawania instytucji funkcjonujących $\mathrm{w}$ tej sferze $\mathrm{w}$ celu realizacji potrzeb społeczeństwa ${ }^{3}$. Na podstawie „Słownika pojęć stosowanych w statystyce publicznej" umieszczonego na stronie internetowej Głównego Urzędu Statystycznego przez pojęcie ,instytucji kultury” rozumie się państwowa lub samorzadowa osobe prawna, dla której działalność kulturalna jest podstawowym celem statutowym (niestanowiącym jednocześnie działalności gospodarczej), prowadzona w szczególności w formie: muzeów, biur wystaw artystycznych, galerii i centrów sztuki, bibliotek, domów i ośrodków kultury, świetlic i klubów ${ }^{4}$. We wspomnianej wyżej ustawie wymieniono więcej form działalności kulturalnej. Zaliczono do nich: teatry, opery, operetki, filharmonie, orkiestry, instytucje filmowe, kina, muzea, biblioteki, domy kultury, ogniska artystyczne, galerie sztuki oraz ośrodki badań i dokumentacji w różnych dziedzinach kultury ${ }^{5}$. Spośród instytucji kultury wyodrębniono te o charakterze artystycznym, a więc działające $w$ dziedzinie teatru, muzyki, tańca, z udziałem twórców i wykonawców ${ }^{6}$ oraz inne placówki kulturalne. W „Ustawie z dnia 25 października 1991 r. o organizowaniu i prowadzeniu działalności kulturalnej” zwrócono również uwagę na sezonowość funkcjonowania instytucji artystycznych, które w porównaniu z pozostałymi działają od 1 września do 31 sierpnia kolejnego roku wedle ustalonych planów repertuarowych.

W artykule poddano analizie instytucje kultury, których wykaz znajduje się na stronie internetowej Starostwa Powiatowego w Zduńskiej Woli ${ }^{7}$. Uznano tę witrynę za najbardziej wiarygodne źródło informacji o obiektach funkcjonujących w powiecie zduńskowolskim. W badaniach przyjęto podział placówek na ośrodki kultury, muzea i biblioteki, zgodnie z klasyfikacją widniejącą na powyższej stronie internetowej.

\footnotetext{
1 Konstytucja Rzeczypospolitej Polskiej z dnia 2 kwietnia 1997 r. (Dz.U. z 1997 r., nr 78, poz. 483 , z późn. zm.), art. 6 ust. 1.

2 Ustawa z dnia 25 października 1991 r. o organizowaniu i prowadzeniu działalności kulturalnej (Dz.U. z 2020 r., poz. 194.), art. 1 ust. 1.

3 https://www.nck.pl/szkolenia-i-rozwoj/projekty/kultura-sie-liczy-/zarzadzanie-kultura/ dzialalnosc-kulturalna [dostęp: 15.03.2020].

4 https://stat.gov.pl/metainformacje/slownik-pojec/pojecia-stosowane-w-statystyce-publicznej/128,pojecie.html [dostęp: 15.03.2020].

5 Ustawa z dnia 25 października 1991 r. o organizowaniu ..., art. 2.

6 Tamże, art. 11, ust. 2.

7 http://www.powiatzdunskowolski.pl/ [dostęp: 15.03.2020].
} 
Kultura stanowi jeden z siedmiu aspektów jakości życia ${ }^{8}$, dlatego odległość instytucji o charakterze kulturalnym od miejsca zamieszkania ma duże znaczenie dla społeczeństwa. W tym miejscu należy wspomnieć o występujących w przestrzeni dysproporcjach. Na zróżnicowanie dostępności obiektów kultury na wsiach i w miastach lub też w małych, średnich i dużych ośrodkach miejskich niewątpliwie wpływa liczba tych obiektów. Łatwiejszy dostęp do omawianych placówek mają mieszkańcy miast, gdzie instytucje tego typu są gęściej rozmieszczone, dzięki czemu jest do nich bliżej’.

Działalność placówek kultury nie ogranicza się jedynie do organizowania wydarzeń wzbudzających zainteresowanie wśród obywateli. Instytucje te mają wpływ na człowieka w znacznie większym stopniu. Na płaszczyźnie społecznej są to korzyści w postaci rozwoju kulturalnego i osiągania prestiżu środowiskowego, a na psychicznej - poprawy wizerunku, wyższej samooceny i rozwoju intelektualnego. Omawiane obiekty oddziałują pozytywnie także na wizerunek danej jednostki osadniczej oraz budzą u społeczności poczucie satysfakcji wynikające z samego faktu występowania na danym obszarze ${ }^{10}$.

Za cel opracowania przyjęto ocenę dostępności pieszej, rowerowej i samochodowej do ośrodków kultury, muzeów i bibliotek znajdujących się na terenach miejskich i wiejskich powiatu zduńskowolskiego. W opracowaniu nie uwzględniono transportu zbiorowego, gdyż w ostatnich latach można zaobserwować zdecydowany wzrost dostępu do indywidualnych środków transportu, co poskutkowało zwiększeniem się liczby ich użytkowników przy jednoczesnym zmniejszeniu się zapotrzebowania wśród obywateli na podróżowanie transportem zbiorowym ${ }^{11}$. Tomasz Komornicki i in. (2009) ${ }^{12}$ proponują podział metod badania i pomiaru dostępności transportowej na sześć podejść. Wyróżniają oni dostępność mierzoną: maksymalizacją użyteczności, izochronami, za pomocą wskaźników wyposażenia infrastrukturalnego, odległością, możliwością zajścia interakcji pomiędzy punktem startowym a celami podróży oraz dostępność mierzoną w geografii czasu lub czasoprzestrzeni. W niniejszym opracowaniu zdecydowano się na użycie powszechnie wykorzystywanej w badaniach dostępności metody izochron, po-

8 J. Sanetra-Szeliga, Kultura jako element składowy jakości życia w mieście, „Kultura i Rozwój” 2017, nr 1(2), s. 45-59.

9 K. Gorlach (red.), Raport o rozwoju społecznym Polska 2000. Rozwój obszarów wiejskich, UNDP, Warszawa 2000, s. 82.

10 G. Światowy, K. Kuźniak, Miejsce kultury w budowaniu społeczeństwa dobrobytu, „Handel Wewnętrzny” 2017, nr 4(369), s. 425-434.

11 S. Kauf, J. Szołtysek, I. Wieczorek, Transport zbiorowy w zaspokajaniu mobilności mieszkańców miast. Doświadczenia JST, Wydawnictwo NIST, Łódź 2018, s. 51.

12 T. Komornicki, P. Śleszyński, P. Rosik, W. Pomianowski, M. Stępniak, P. Silka, Dostępność przestrzenna jako przesłanka kształtowania polskiej polityki transportowej, „Biuletyn KPZK PAN” 2009 , z. 241, s. 36-37. 
legającej na wyznaczeniu linii jednakowego czasu przejścia bądź przejazdu do danych obiektów.

Dostępność uznawana jest za jedno z podstawowych pojęć występujących w obszarze nauk społecznych. Określa się ją jako zdolność zaistnienia relacji między więcej niż jednym elementem zbioru. Powyższe założenie umożliwia więc wyszczególnienie kluczowych cech dostępności. Pierwsza to występowanie w przestrzeni co najmniej dwóch osiągalnych względem siebie elementów, stanowiących punkt źródłowy i docelowy dostępności. Drugą z właściwości jest istnienie między tymi elementami nośnika relacji pokonującego bariery przyrodnicze, polityczne czy społeczno-ekonomiczne. Geografowie wymieniają kilka rodzajów dostępności, m.in. przestrzenną, komunikacyjną, transportową, czasową, ekonomiczną, społeczną i fizyczną ${ }^{13}$. Badania nad dostępnością instytucji kultury, w tym ośrodków kultury, muzeów i bibliotek, przeprowadzono do tej pory na każdym z trzech poziomów podziału administracyjnego Polski. Krzysztof Pokonieczny i in. $(2017)^{14}$ dokonali analizy dostępności Biblioteki Narodowej w Warszawie. Simon Huhndorf i Jarosław Działek (2017) ${ }^{15}$ wzięli pod uwagę biblioteki w Krakowie. Główny Urząd Statystyczny w jednym z raportów ${ }^{16}$ przedstawił dostępność mieszkańców Polski do wybranych obiektów użyteczności publicznej (w układzie gminnym), wśród których znalazły się domy kultury i biblioteki. Joanna Dominiak $(2011)^{17}$ zajmowała się dostępnością m.in. ośrodków kultury i muzeów, mieszczących się na terenie województwa wielkopolskiego, z uwzględnieniem jego podziału na jednostki niższego rzędu. Jako przykład analizy dostępności placówek kulturalnych za granicą należy wymienić publikację Anny Winiarczyk-Raźniak $(2009)^{18}$. Jednymi z podmiotów pracy autorki były meksykańskie muzea. $Z$ kolei Yike Guo i in. (2017) ${ }^{19}$ zbadali dostępność bibliotek w Hongkongu.

13 Tamże, s. 16, 19.

14 K. Pokonieczny, J. Tomala, A. Mościcka, Porównanie dostępności czasowej wyznaczanej z wykorzystaniem różnych serwisów internetowych, „Roczniki Geomatyki” 2017, t. 15, z. 1(76), s. 97-106.

15 S. Huhndorf, J. Działek, Assessment of the walking accessibility of public libraries in Krakow using the E2SFCA approach, „Urban Development Issues” 2017, t. 54, nr 2, s. 5-14.

16 Wskaźniki dostępności terytorialnej mieszkańców Polski do wybranych obiektów użyteczności publicznej, GUS, Warszawa 2018.

17 J. Dominiak, Dostępność uslug publicznych na terenie województwa wielkopolskiego, IGSEiGP, UAM, Poznań 2009.

18 A. Winiarczyk-Raźniak, Dostępność do ustug kulturalnych w Meksyku, „Prace Komisji Geografii Przemysłu PTG” 2009, nr 14, s. 121-129.

19 Y. Guo, C.H. Chan, P.S.F. Yip, Spatial variation in accessibility of libraries in Hong Kong, „Library \& Information Science Research” 2017, t. 39, nr 4, s. 319-329. 


\section{METODOLOGIA}

Za miarę dostępności przyjęto czas dojścia oraz dojazdu rowerem i samochodem do dwudziestu dziewięciu instytucji kultury. Do przeprowadzenia badań wykorzystano dane zaczerpnięte m.in. z wolnego zasobu baz danych informacji przestrzennej OpenStreetMap ${ }^{20}$. Pomysłodawca tego projektu to Steve Coast, którego zamierzeniem było utworzenie dostępnej dla każdego mapy świata, którą można swobodnie edytować ${ }^{21}$. Czas przejazdu samochodem obliczono na podstawie dopuszczalnych prędkości przejazdowych dla poszczególnych kategorii dróg (tab. 1). Na potrzeby oszacowania dostępności rowerowej zwyczajowo przyjętą prędkość ruchu rowerzysty wynoszącą $10-20 \mathrm{~km} / \mathrm{h}^{22}$ uśredniono do $15 \mathrm{~km} / \mathrm{h}$. Średnią prędkość pieszego ustalono na poziomie około $5 \mathrm{~km} / \mathrm{h}^{23}$.

Tablica 1. Klasyfikacja dróg w zasobie OpenStreetMap z dopuszczalnymi prędkościami przejazdowymi

\begin{tabular}{|c|c|}
\hline Klasyfikacja drogi w zasobie OpenStreetMap & Prędkość $[\mathrm{km} / \mathrm{h}]$ \\
\hline Motorway - autostrada & 140 \\
\hline Trunk - droga ekspresowa & 120 \\
\hline Primary - droga krajowa (w Polsce) & 90 \\
\hline Secondary - droga wojewódzka (w Polsce) & 90 \\
\hline Tertiary - droga powiatowa (w Polsce) & 50 \\
\hline Unclassified - droga gminna (w Polsce) & 50 \\
\hline Residential - droga osiedlowa & 20 \\
\hline Livingstreet - droga w strefie zamieszkania & 20 \\
\hline Track - droga gruntowa & 20 \\
\hline
\end{tabular}

Źródło: opracowanie własne na podstawie Borowska-Stefańska M., Dostępność transportowa od straży pożarnych do obiektów spolecznych zlokalizowanych na terenach zagrożonych powodziami $w$ województwie łódzkim z wykorzystaniem analiz sieciowych, „Transport Miejski i Regionalny" 2016, nr 3, s. 28-32.

20 https://download.geofabrik.de/europe/poland.html [dostęp: 15.03.2020].

21 P. Drop, P. Gajewski, M. Mackiewicz, Zastosowanie danych OpenStreetMap oraz wolnego oprogramowania do badań dostępności komunikacyjnej w skali lokalnej, „Acta Universitatis Lodziensis. Folia Geographica Socio-Oeconomica" 2013, nr 14, s. 157-167.

${ }^{22}$ R. Kałuża, P. Czech, T. Figlus, P. Gustof, K. Turoń, Proces hamowania rowerów, „Autobusy" 2018, nr 220(6), s. 115-120.

23 B. Majewski, M. Beim, Dostępność komunikacji publicznej w Poznaniu, [w:] T. Czyż, T. Stryjakiewicz, P. Churski (red.), Nowe kierunki i metody $w$ analizie regionalnej, Biuletyn IGSEiGP UAM, Seria „Rozwój Regionalny i Polityka Regionalna”, nr 3, Bogucki Wydawnictwo Naukowe, Poznań 2008. 
Granicę administracyjną powiatu zduńskowolskiego uznano za nieprzenikliwą i nie brano pod uwagę potencjalnych użytkowników ruchu spoza omawianej jednostki. Najbardziej istotna niedoskonałość takiego podejścia to przyjęcie założenia, że mieszkańcy powiatu zduńskowolskiego korzystają wyłącznie z oferty instytucji kultury zlokalizowanych na terenie tego powiatu. Za pomocą oprogramowania GIS wyeksportowano drogi, po czym wykonano obliczenia przy użyciu narzędzia do analiz sieciowych. Pozwalają one na wyznaczenie obszarów obsługiwanych w określonym czasie, opierając się na krawędziach i wierzchołkach tworzących sieć ${ }^{24}$, w tym przypadku sieć drogową i ciągi piesze. W rezultacie przedstawiono liczby mieszkańców powiatu zduńskowolskiego w zasięgu obszarów ograniczonych izochronami: do 5 minut, od ponad 5 do 10 minut oraz od ponad 10 do 15 minut pieszo, rowerem i samochodem od wybranych instytucji kultury. Wykorzystano do tego udostępnioną na stronie Geoportalu usługę sieciową WMS $^{25}$, która prezentuje aktualną Bazę Danych Obiektów Topograficznych ${ }^{26}$. Wartość izochrony granicznej określono w ślad za Jakubem Zasiną i Wiktorem Wróblewskim (2016) ${ }^{27}$. Za akceptowalny czas pieszego dotarcia do biblioteki w mieście uznali oni 15 minut. By możliwe było późniejsze porównanie uzyskanych wyników, wygenerowano podczas analiz dostępności pieszej, rowerowej i samochodowej do każdej kategorii placówek izochrony o jednakowych wartościach. Należy w tym miejscu zaznaczyć, że mieszkańcy miast mają zupełnie inne poczucie odległości niż osoby mieszkające w małych miejscowościach. Ci pierwsi są bardziej mobilni i bez trudu udają się na drugi koniec miasta, oddalony o kilka lub kilkanaście kilometrów. Z kolei ci drudzy często niechętnie przemieszczają się do sąsiedniej miejscowości, traktując tę czynność niczym wyprawę ${ }^{28}$. W sytuacji gdy mieszkaniec wsi chce skorzystać z oferty obiektów użyteczności publicznej, jest on zmuszony do pokonania znacznie większego dystansu niż osoba mieszkająca w mieście. Wynika to chociażby z dekoncentracji zabudowy na obszarach pozamiejskich.

Liczbę ludności zamieszkałej w poszczególnych przedziałach czasowych obliczono dzieląc ogólną liczbę mieszkańców analizowanego obszaru z 2018 r. przez sumę powierzchni zabudowy mieszkaniowej. Otrzymany wynik pomnożono

24 E. Dębińska, P. Cichociński, K. Krystek, Problemy prowadzenia analiz sieciowych w przestrzeni trójwymiarowej z wykorzystaniem oprogramowania Network Analyst (ArcGIS) i pgRouting (PostGIS), „Roczniki Geomatyki” 2017, t. 15, z. 3(78), s. 271-282.

25 https://mapy.geoportal.gov.p1/wss/service/pub/guest/G2_SKOROWIDZE_BDOT/MapServer/WMSServer [dostęp: 15.03.2020].

${ }^{26} \mathrm{http} / /$ www.gugik.gov.pl/pzgik/zamow-dane/baza-danych-obiektow-topograficznych-bdot-10k [dostęp: 15.03.2020].

27 J. Zasina, W. Wróblewski, Piesza dostępność udogodnień a struktura przestrzenna starzejącego się miasta, „Studia Ekonomiczne Regionu Łódzkiego” 2016, nr 21, s. 165-176.

28 M. Bogacki, K.M. Turosieńska-Durlik, Rola instytucji kultury w społecznościach wiejskich, na przykładzie gminy Mielnik w województwie podlaskim, Wydawnictwo Arte, Mielnik 2011. 
przez powierzchnię budynków mieszkalnych zlokalizowanych w zasięgu obszarów ograniczonych ustalonymi izochronami, wrysowanymi dla każdej z badanych grup obiektów. Obliczenia wykonywano osobno dla zabudowy mieszkaniowej jedno- i wielorodzinnej. Słabość powyższych kalkulacji polega przede wszystkim na założeniu równomiernego rozmieszczenia ludności względem budynków o funkcji mieszkalnej, podczas gdy ludność z terenów zurbanizowanych i wiejskich nie zamieszkuje zabudowy w tak uśredniony sposób.

\section{CHARAKTERYSTYKA OBSZARU BADAŃ}

W skład powiatu zduńskowolskiego wchodzą cztery gminy: Zduńska Wola (miejska), Szadek (miejsko-wiejska), Zduńska Wola (wiejska) oraz Zapolice (wiejska). W ich granicach znajduje się siedem ośrodków kultury, sześć muzeów i szesnaście bibliotek. Spośród placówek kultury wymienionych na stronie internetowej starostwa powiatowego nie brano pod uwagę Szkolnego Schroniska Młodzieżowego i Powiatowego Międzyszkolnego Ośrodka Sportowego w Zduńskiej Woli, przynależnych do Powiatowego Centrum Kultury, Sportu i Rekreacji. Uwzględniono wyłącznie Powiatowy Młodzieżowy Dom Kultury, ponieważ tylko ta placówka prowadzi działalność kulturalną. W wykazie instytucji kulturalnych znalazły się też m.in. Dom Kultury „Lokator” (działający jako agenda jednej ze zduńskowolskich spółdzielni mieszkaniowych o tej samej nazwie) oraz Biblioteka Zgromadzenia Księży Orionistów w Zduńskiej Woli. Mimo że nie są to placówki samorządowe, postanowiono nie wykluczać ich $\mathrm{z}$ analiz. Zdecydowana większość ośrodków kultury mieści się w granicach miasta stanowiącego siedzibę omawianego powiatu. Dwa pozostałe funkcjonują w gminach Zapolice i Szadek. Odległość w linii prostej między tymi instytucjami wynosi od 0,3 km (między dwoma obiektami należącymi do Miejskiego Domu Kultury w Zduńskiej Woli) do 17,2 km (między Gminnym Ośrodkiem Kultury i Sportu w Zapolicach a Miejsko-Gminnym Ośrodkiem Kultury w Szadku). Muzea również znajdują się głównie w granicach miasta Zduńska Wola. Wyjątek stanowią dwie izby muzealne przy szkołach w Wojsławicach i w Prusinowicach. Najkrótszy dystans w linii prostej dzieli Muzeum Historii Miasta Zduńska Wola od Domu Urodzenia Świętego Maksymiliana Marii Kolbego $(0,3 \mathrm{~km})$, natomiast najdłuższy Przyszkolną Izbę Muzealną w Prusinowicach od Skansenu Lokomotyw i Urządzeń Technicznych, stanowiącego Filię Muzeum Historii Miasta Zduńska Wola (18,7 km).

W odniesieniu do bibliotek wykorzystano do analiz czternaście lokalizacji, ponieważ Miejska Biblioteka Publiczna im. Jerzego Szaniawskiego w Zduńskiej Woli oraz dwa jej oddziały (Filia Biblioteczna nr 1 oraz Filia Biblioteczna dla Dzieci i Młodzieży) funkcjonują pod tym samym adresem. Biblioteki w powiecie 
zduńskowolskim są położone w odległości od 0,3 km (Biblioteka Pedagogiczna w Sieradzu - filia w Zduńskiej Woli od Miejskiej Biblioteki Publicznej w Zduńskiej Woli) do nawet 28,6 km (Miejska i Gminna Biblioteka Publiczna w Szadku - Filia Biblioteczna w Krokocicach od Gminnej Biblioteki Publicznej w Zapolicach - Filii Bibliotecznej w Rembieszowie), mierzonej w linii prostej.

$\mathrm{Z}$ analizy typów zabudowy mieszkaniowej na omawianym obszarze wynika, że przeważająca część budynków wielorodzinnych w powiecie występuje w Zduńskiej Woli. Spośród nieco ponad 13568 budynków mieszkalnych około $95,9 \%$ stanowi zabudowa o charakterze jednorodzinnym. Na podstawie opisanej wcześniej metody oszacowano, że na 66766 osób zameldowanych w powiecie zduńskowolskim ${ }^{29} 36,8 \%$ ludności mieszka w zabudowaniach wielorodzinnych.

\section{DOSTĘPNOŚĆ PIESZA}

\section{Ośrodki kultury}

Obszary ograniczone izochronami dojścia do ośrodków kultury zajmują $10,5 \mathrm{~km}^{2}$, co przy ogólnej powierzchni powiatu ${ }^{30}$ wynoszącej $369 \mathrm{~km}^{2}$ stanowi $2,8 \%$ jego terytorium. Do 5 minut piechotą do ośrodków kultury są w stanie dotrzeć 992 osoby mieszkające w domach jednorodzinnych. Liczba osób z budynków wielorodzinnych w tej strefie wynosi 5510 . W zasięgu strefy dotarcia pieszo do ośrodków kultury w czasie od powyżej 5 do 10 minut mieszka 11520 osób, z czego 3226 mieszka w zabudowie jednorodzinnej. Strefa dojścia od powyżej 10 do 15 minut obejmuje zbliżone liczby mieszkańców domów jednorodzinnych i wielopiętrowych obiektów mieszkaniowych, które wynoszą odpowiednio 6291 i 6485. Najbardziej charakterystyczne, wydłużone kształty przybierają obszary ograniczone izochronami wyznaczonymi wokół Gminnego Ośrodka Kultury i Sportu w Zapolicach, czego powodem jest mało rozbudowana sieć komunikacyjna. Można na tej podstawie wysunąć wniosek, że powyższa placówka cechuje się najgorszą dostępnością pieszą spośród pozostałych sześciu instytucji w powiecie (ryc. 1). Należy zwrócić uwagę także na izochrony wyznaczone od Filii Miejskiego Domu Kultury w Zduńskiej Woli. Wpływ na ich rozkład ma niewątpliwie linia kolejowa biegnąca tuż przy wschodniej i południowo-wschodniej granicy miasta.

\footnotetext{
29 https://bdl.stat.gov.pl/BDL/dane/teryt/tablica [dostęp: 15.03.2020].

30 Tamże.
} 


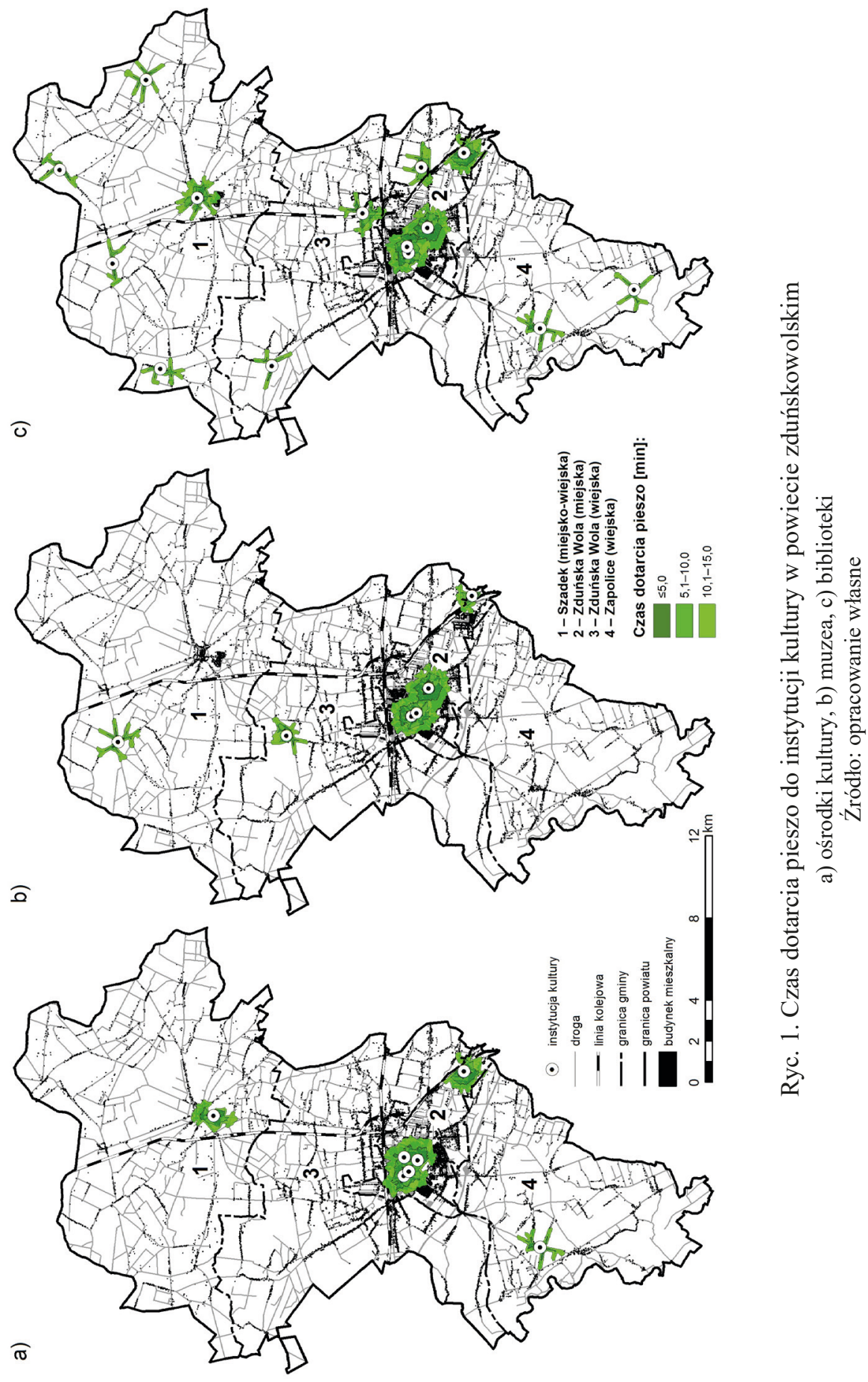




\section{Muzea}

Strefa dojścia do 15 minut do muzeów pokrywa $9,7 \mathrm{~km}^{2}$. Mimo jednej instytucji mniej niż w przypadku ośrodków kultury, stanowi tylko o $0,2 \%$ mniejszą powierzchnię powiatu zduńskowolskiego objętą izochronami. W ciągu maksymalnie 5 minut do muzeów może dotrzeć 614 osób z domów jednorodzinnych i 1624 z zabudowy wielorodzinnej. Od powyżej 5 do 10 minut do placówek muzealnych jest w stanie dojść 2745 mieszkańców budynków jednorodzinnych oraz 4702 osoby zameldowane $\mathrm{w}$ zabudowaniach wielokondygnacyjnych. Izochrona dotarcia pieszego do muzeów od powyżej 10 do 15 minut obejmuje 4476 osób mieszkających w zabudowie jednorodzinnej i 11601 osób w obiektach wielorodzinnych. Nietypowe kształty przyjmują izochrony wrysowane wokół Przyszkolnej Izby Muzealnej w Prusinowicach w gminie Szadek oraz Izby Regionalnej przy Zespole Szkół Rolniczych Centrum Kształcenia Ustawicznego w Wojsławicach w gminie wiejskiej Zduńska Wola. Warto również podkreślić, że dojście do Skansenu Lokomotyw i Urządzeń Technicznych jest znacząco utrudnione od strony południowej z uwagi na mieszczący się tam Zakład Napraw Taboru ${ }^{31}$.

\section{Biblioteki}

Powierzchnia obszarów ograniczonych izochronami dojścia do bibliotek w powiecie zduńskowolskim w ciągu maksymalnie 15 minut wynosi około 20,3 km², co stanowi w przybliżeniu 5,5\% terytorium badanego obszaru. Czytelnicy, którzy mają możliwość dotarcia do bibliotek piechotą w czasie nie dłuższym niż 5 minut, to 1683 mieszkańców zabudowy jednorodzinnej i 3625 osób z budynków wielokondygnacyjnych. W ciągu od powyżej 5 do 10 minut omawiane instytucje są dostępne pieszo dla 11966 osób, w tym dla 4478 osób zameldowanych w domach jednorodzinnych. Z kolei w strefie dojścia od powyżej 10 do 15 minut znajduje się 7542 mieszkańców zabudowy jednorodzinnej i 8010 osób zamieszkujących budynki wielorodzinne. Największy odsetek potencjalnych czytelników, mających możliwość dojścia do biblioteki w kwadrans, stanowią mieszkańcy Zduńskiej Woli, Szadku i Janiszewic. Wynika to z występujących dużych skupisk zabudowy mieszkaniowej jedno- $\mathrm{i}$ wielorodzinnej w izochronach wyznaczonych od: Biblioteki Zgromadzenia Księży Orionistów, Miejskiej Biblioteki Publicznej im. Jerzego Szaniawskiego, zduńskowolskiej filii Biblioteki Pedagogicznej w Sieradzu, Miejskiej i Gminnej Biblioteki Publicznej w Szadku oraz filii zduńskowolskiej biblioteki miejskiej w Janiszewicach. Rozmieszczenie zabudowy wewnątrz obszarów ograniczonych izochronami wrysowanymi dla pozostałych bibliotek wskazuje na dużo gorszą dostępność tych instytucji dla społeczności na terenach oddalonych od ośrodków miejskich. Są one dostępne w strefie dojścia do 15 minut tylko dla okolicznych mieszkańców.

${ }^{31}$ https://cargotabor.pl/o-firmie/mapa.html\# [dostęp: 15.03.2020]. 


\section{DOSTĘPNOŚĆ ROWEROWA}

\section{Ośrodki kultury}

Strefy dojazdu rowerem do obiektów kultury zajmują $68,8 \mathrm{~km}^{2}$ i tym samym stanowią 18,6\% ogólnej powierzchni powiatu. W obrębie pięciominutowej izochrony mieszka 30155 osób, w tym 20130 osób w budynkach wielopiętrowych. Potencjalni bywalcy ośrodków kultury, którzy mają możliwość dojazdu do nich rowerem w ciągu od powyżej 5 do 10 minut, to 10339 mieszkańców zabudowy jednorodzinnej i 4114 osób zameldowanych w zabudowaniach wielokondygnacyjnych. W kolejnej strefie znajduje się łącznie 7439 osób z domów jednorodzinnych i tylko 74 mieszkańców zabudowy wielorodzinnej. Wyznaczone strefy dojazdu rowerem do ośrodków kultury pokrywają wszystkie zabudowania pełniące funkcję mieszkalną w Zduńskiej Woli. Zasięg izochron wokół analizowanych placówek w tym mieście wykracza poza granice jednostki, głównie w kierunkach: północno-zachodnim, północnym, północno- i południowo-wschodnim (ryc. 2). W przypadku Gminnego Ośrodka Kultury i Sportu w Zapolicach strefy dojazdu rowerem pokrywają w całości zabudowę mieszkaniową w Zapolicach i w sąsiadującym z nimi od północy Marcelowie.

\section{Muzea}

Izochrony dojazdu do placówek muzealnych w powiecie zduńskowolskim obejmują 70,7 km², co stanowi 19,2\% jego łącznej powierzchni. Liczba mieszkańców będących w stanie dotrzeć rowerem do muzeów w maksymalnie 5 minut wynosi 24 212, z czego 7418 to osoby zameldowane w zabudowie jednorodzinnej. Obszar dojazdu od powyżej 5 do 10 minut obejmuje swoim zasięgiem 10665 mieszkańców domów jednorodzinnych i 6752 osób mieszkających w budynkach wielopiętrowych. W ostatniej izochronie znajduje się 7510 osób zamieszkałych w zabudowie jednorodzinnej oraz $80 \mathrm{w}$ wielorodzinnej. Strefy dojazdu rowerem wrysowane od Izby Regionalnej w Wojsławicach i wszystkich muzeów w Zduńskiej Woli pokrywają się ze sobą w szczególności w przedziale od powyżej 10 do 15 minut. Dostęp do izby muzealnej funkcjonującej przy Zespole Szkół Rolniczych Centrum Kształcenia Ustawicznego jest w znacznym stopniu utrudniony od strony północno-zachodniej. 


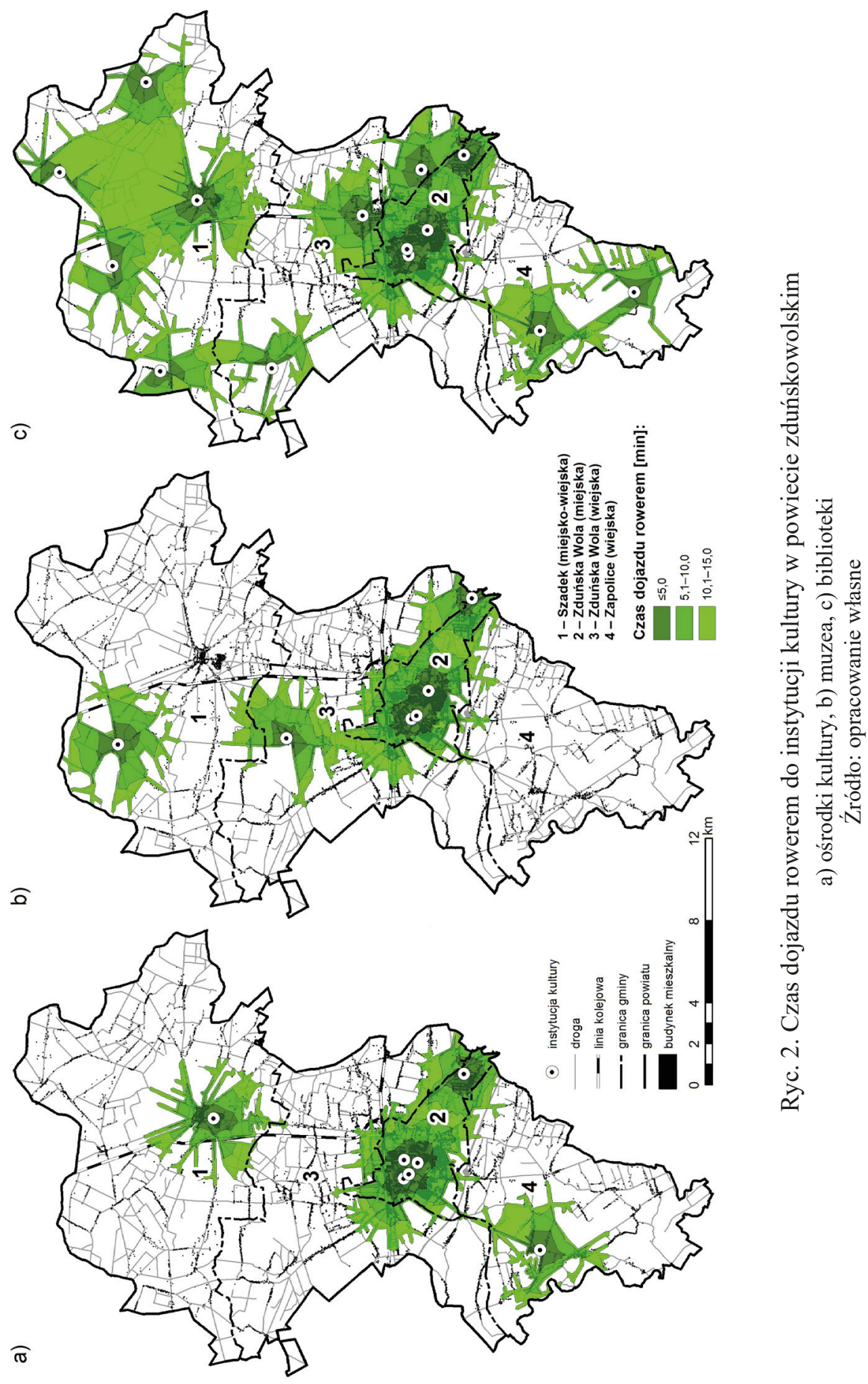




\section{Biblioteki}

Obszary ograniczone izochronami dojazdu rowerem do bibliotek w powiecie zduńskowolskim zajmują 162,4 km², czyli około 44\% ogólnej powierzchni analizowanej jednostki. Do 5 minut rowerem do omawianych placówek jest w stanie dotrzeć 12808 mieszkańców domów jednorodzinnych. Z kolei liczba osób mieszkających w zabudowaniach wielorodzinnych w tej strefie wynosi 18554 . Powyżej 5 minut do 10 minut to czas, w którym do biblioteki może dotrzeć 13930 osób z zabudowy jednorodzinnej i 5814 mieszkańców wielokondygnacyjnych obiektów. W strefie dojazdu od powyżej 10 do 15 minut znajduje się 7754 mieszkańców budynków jednorodzinnych i jedynie 49 osób zameldowanych w zabudowaniach wielopiętrowych. Na uwagę zasługują izochrony wyznaczone od biblioteki miejskiej w Szadku oraz trzech jej filii - w Krokocicach, Prusinowicach-Parceli i Górnej Woli, tworzące duży w stosunku do innych izochron obszar, z którego czytelnicy w kwadrans dojadą rowerem w celu wypożyczenia książek. Najciekawszy kształt przyjmują natomiast izochrony poprowadzone od filii Biblioteki Publicznej im. Jerzego Szaniawskiego w Zduńskiej Woli, mieszczącej się w miejscowości Annopole Stare. Powierzchnia strefy dojazdu rowerem do tego oddziału w ciągu 5 minut jest najmniejsza w porównaniu z izochronami wyznaczonymi dla pozostałych tego typu instytucji.

\section{DOSTĘPNOŚĆ SAMOCHODOWA}

\section{Ośrodki kultury}

Izochrony dojazdu w ciągu maksymalnie 15 minut do ośrodków kultury, działających na terenie powiatu, obejmują około $266,8 \mathrm{~km}^{2}$. Obszar ten stanowi $72,3 \%$ ogólnej powierzchni badanego terytorium. Spośród 40706 osób mających możliwość dojazdu do omawianych placówek samochodem w czasie 5 minut, 17056 z nich mieszka w domach jednorodzinnych. Mieszkańcy zabudowy jednorodzinnej w liczbie 14386 oraz 707 osób zameldowanych w budynkach wielokondygnacyjnych mogą dotrzeć do ośrodków kultury w powiecie zduńskowolskim, spędzając za kierownicą od powyżej 5 do 10 minut. W zasięgu izochrony od powyżej 10 do 15 minut 8537 osób mieszka w zabudowie jednorodzinnej, a 234 osoby w wielorodzinnej. Dostępu do ośrodków kultury w czasie do 15 minut pozbawieni są mieszkańcy południowej, północno-wschodniej i północno-zachodniej części powiatu oraz nieliczni zameldowani na południowym zachodzie (ryc. 3). Warto podkreślić, że wszyscy zduńskowolanie, z wyjątkiem mieszkańców kilku budynków jednorodzinnych na północy miasta, mogą dojechać samochodem do ośrodka kultury w maksymalnie 10 minut. Osoby pochodzące z północnych obszarów gminy wiejskiej Zduńska Wola są w stanie dotrzeć do najbliżej położonych instytucji w większości w ciągu od powyżej 10 do 15 minut. 


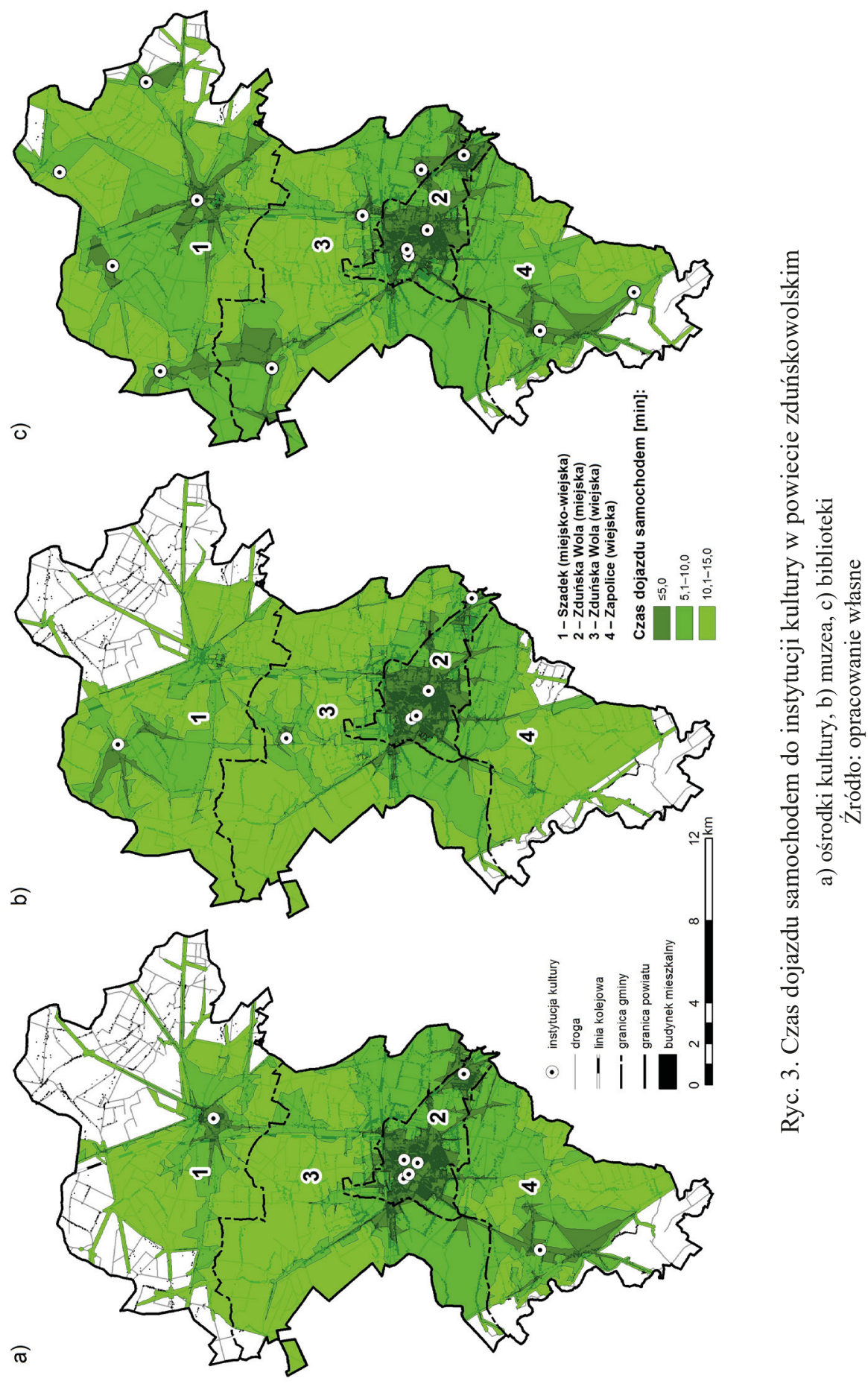




\section{Muzea}

Strefa dojazdu samochodem w ciągu do 15 minut do placówek muzealnych w powiecie pokrywa $284,3 \mathrm{~km}^{2}$, a więc około $77 \%$ jego całkowitej powierzchni. Dojazd do najbliższego muzeum zajmujący do 5 minut jest możliwy dla 12814 osób z domów jednorodzinnych oraz 22435 mieszkańców zabudowy wielopiętrowej. W zasięgu izochrony dojazdu od powyżej 5 do 10 minut mieszka w sumie 16467 osób, ale aż 14560 z nich to ludność zameldowana w budynkach jednorodzinnych. Potencjalni bywalcy muzeów, mający możliwość dojazdu do nich samochodem w ciągu od powyżej 10 do 15 minut, to 12897 osób z domów jednorodzinnych i 249 mieszkańców budynków wielorodzinnych. Utrudniony dostęp do omawianych instytucji mają osoby pochodzące ze wschodnich i północno-wschodnich obszarów gminy Szadek. W takiej sytuacji znajdują się także wybrani mieszkańcy gminy Zapolice, którzy by odwiedzić placówkę muzealną, muszą dojechać do jednej z czterech takich instytucji działających w Zduńskiej Woli.

\section{$\underline{\text { Biblioteki }}$}

Izochrony dojazdu samochodem do bibliotek obejmują $339,4 \mathrm{~km}^{2}$, co stanowi 92\% ogólnej powierzchni analizowanego powiatu. Do omawianych placówek podczas maksymalnie 5 minut ma możliwość dotrzeć 16929 czytelników, mieszkających w domach jednorodzinnych. Z kolei liczba osób zameldowanych w zabudowie wielorodzinnej i będących w stanie dojechać do bibliotek w tym czasie wynosi 20945. Mieszkańcy zabudowy jednorodzinnej w liczbie 17418 oraz 3491 osób z budynków wielokondygnacyjnych mogą dotrzeć do bibliotek po spędzeniu za kierownicą od powyżej 5 do 10 minut. W ostatniej strefie dojazdu samochodem 7471 osób mieszka w domach jednorodzinnych, a 154 w obiektach wielopiętrowych. W najkrótszym czasie do bibliotek mają możliwość dostać się mieszkańcy Zduńskiej Woli, ponieważ izochrona pięciominutowego dojazdu samochodem do omawianych instytucji w granicach miasta pokrywa zdecydowaną większość zabudowy o funkcji mieszkalnej. Na podstawie prawie niewidocznej pięciominutowej strefy dojazdu do filii Miejskiej i Gminnej Biblioteki Publicznej w Szadku, zlokalizowanej w Krokocicach, można stwierdzić, że obiekt ten cechuje się najgorszym poziomem dostępności samochodowej spośród wszystkich bibliotek.

\section{WNIOSKI}

Na podstawie przeprowadzonych badań stwierdzono, że najlepszą dostępnością czasową odznaczają się biblioteki. Zważywszy na mniejszą o jeden liczbę muzeów w stosunku do liczby ośrodków kultury, instytucje muzealne charakteryzują się nieznacznie lepszą dostępnością samochodową, lecz mimo to ich ogólna dostępność dla populacji powiatu zduńskowolskiego jest nadal najsłabsza spośród badanych 
kategorii instytucji. Odsetek ogółu mieszkańców powiatu zduńskowolskiego będących w stanie dotrzeć samochodem do ośrodków kultury wynosi 96,7\%. Do muzeów i bibliotek tym środkiem lokomocji może dojechać jeszcze więcej osób (tab. 2).

Tablica 2. Liczba osób mieszkających w wyznaczonych izochronach dotarcia do ośrodków kultury, muzeów i bibliotek w powiecie zduńskowolskim



Źródło: opracowanie własne

Dla ludności mieszkającej w zabudowie wielokondygnacyjnej najtrudniej dostępne obiekty w czasie 15 minut pieszo czy przy wykorzystaniu roweru to muzea. Świadczą o tym odsetki mieszkańców w zasięgu izochron, wynoszące 
odpowiednio 72,9 oraz $96,1 \%$. Z kolei wszystkie osoby zameldowane w budynkach wielorodzinnych są w stanie w maksymalnie 15 minut dojechać samochodem do najbliższej biblioteki. Mieszkańcy domów jednorodzinnych, w zależności od sposobu przemieszczania się, mają najgorszy dostęp pieszy do muzeów, do których w 15 minut ma możliwość dotarcia jedynie 18,6\% z nich. Najwięcej osób z zabudowy mieszkaniowej jednorodzinnej, bo około 99,2\%, może natomiast dojechać samochodem do biblioteki.

Po przeanalizowaniu wyników obliczeń uwidacznia się zależność, która polega na zmniejszaniu się liczby mieszkańców zabudowy wielopiętrowej, mających dostęp do badanych obiektów kultury przy wykorzystaniu roweru czy samochodu, wraz z wydłużającym się czasem dotarcia do tych instytucji. W przypadku ludności z domów jednorodzinnych najwięcej osób dojeżdżających rowerem do ośrodków kultury, muzeów i bibliotek mieszka w zasięgu izochrony o wartości od powyżej 5 do 10 minut. Zważywszy na analizy dostępności pieszej, liczba mieszkańców budynków jedno- i wielorodzinnych na ogół wzrasta wraz ze zwiększającymi się wartościami izochron.

Podsumowując, najlepszy dostęp do instytucji kultury mają mieszkańcy Zduńskiej Woli. Wynika to z rozmieszczenia poszczególnych placówek w granicach miasta oraz występujących tu największych skupisk wielorodzinnej zabudowy mieszkaniowej. Zaobserwowano, że izochrony wyznaczone dla Miejskiej Biblioteki Publicznej w Zduńskiej Woli, filii sieradzkiej biblioteki pedagogicznej i Biblioteki Zgromadzenia Księży Orionistów pokrywają się ze sobą w analizach dostępności pieszej, a w analizach dostępności rowerowej i samochodowej nakładają się na siebie w jeszcze większym stopniu, nawet z izochronami poprowadzonymi od innych bibliotek. Taka sama sytuacja występuje w odniesieniu do Domu Urodzenia Świętego Maksymiliana Marii Kolbego, Muzeum Dziejów Zgromadzenia Księży Orionistów oraz Muzeum Historii Miasta Zduńska Wola, a także trzech ośrodków kultury zlokalizowanych w Zduńskiej Woli. Na dostępność lokalnej społeczności do placówek kulturalnych niewątpliwie wpływa brak muzeum w gminie Zapolice oraz ośrodka kultury w gminie wiejskiej Zduńska Wola. Poziom dostępności do badanych obiektów warunkuje również układ dróg i ciągów pieszych oraz przebieg linii kolejowych. Zróżnicowanie dostępności dla mieszkańców analizowanego powiatu do ośrodków kultury, muzeów i bibliotek wynika z liczby i położenia poszczególnych placówek kultury oraz z rozmieszczenia zabudowy mieszkaniowej jedno- i wielorodzinnej. Przy prowadzeniu polityki lokalnej należy zadbać o nowe lokalizacje tych instytucji i planować ich rozmieszczenie w taki sposób, aby przyczyniały się one do jeszcze lepszego zaspokojenia potrzeb lokalnej społeczności w zakresie kultury, w szczególności na terenach wiejskich. 


\section{Bibliografia}

\section{Opracowania}

Bogacki M., Turosieńska-Durlik K.M., Rola instytucji kultury w społecznościach wiejskich, na przyktadzie gminy Mielnik w województwie podlaskim, Wydawnictwo Arte, Mielnik 2011.

Borowska-Stefańska M., Dostępność transportowa od straży pożarnych do obiektów spolecznych zlokalizowanych na terenach zagrożonych powodziami w województwie tódzkim z wykorzystaniem analiz sieciowych, „Transport Miejski i Regionalny” 2016, nr 3, s. 28-32.

Dębińska E., Cichociński P., Krystek K., Problemy prowadzenia analiz sieciowych w przestrzeni trójwymiarowej z wykorzystaniem oprogramowania Network Analyst (ArcGIS) i pgRouting (PostGIS), „Roczniki Geomatyki” 2017, t. 15, z. 3(78), s. 271-282.

Dominiak J., Dostęność ustug publicznych na terenie województwa wielkopolskiego, IGSEiGP, UAM, Poznań 2009.

Drop P., Gajewski P., Mackiewicz M., Zastosowanie danych OpenStreetMap oraz wolnego oprogramowania do badań dostępności komunikacyjnej w skali lokalnej, „Acta Universitatis Lodziensis. Folia Geographica Socio-Oeconomica” 2013, nr 14, s. $157-167$.

Gorlach K. (red.), Raport o rozwoju społecznym - Polska 2000. Rozwój obszarów wiejskich, UNDP, Warszawa 2000, s. 82.

Guo Y., Chan C.H., Yip P.S.F., Spatial variation in accessibility of libraries in Hong Kong, „Library \& Information Science Research” 2017, t. 39, nr 4, s. 319-329.

Huhndorf S., Działek J., Assessment of the walking accessibility of public libraries in Krakow using the E2SFCA approach, „Urban Development Issues” 2017, t. 54, nr 2, s. $5-14$.

Kałuża R., Czech P., Figlus T., Gustof P., Turoń K., Proces hamowania rowerów, „Autobusy" 2018, nr 220(6), s. 115-120.

Kauf S., Szołtysek J., Wieczorek I., Transport zbiorowy w zaspokajaniu mobilności mieszkańców miast. Doświadczenia JST, Wydawnictwo NIST, Łódź 2018, s. 51.

Komornicki T., Śleszyński P., Rosik P., Pomianowski W., Stępniak M., Silka P., Dostępność przestrzenna jako przesłanka ksztaltowania polskiej polityki transportowej, „Biuletyn KPZK PAN” 2009, z. 240, s. 16, 19, 36-37.

Konstytucja Rzeczypospolitej Polskiej z dnia 2 kwietnia 1997 r. (Dz.U. z 1997 r., nr 78, poz. 483 , z późn. zm.), art. 6 ust. 1.

Majewski B., Beim M., Dostępność komunikacji publicznej w Poznaniu, [w:] T. Czyż, T. Stryjakiewicz, P. Churski (red.), Nowe kierunki i metody $w$ analizie regionalnej, Biuletyn IGSE i GP UAM, Seria „Rozwój Regionalny i Polityka Regionalna”, nr 3, Bogucki Wydawnictwo Naukowe, Poznań 2008. 
Pokonieczny K., Tomala J., Mościcka A., Porównanie dostepności czasowej wyznaczanej z wykorzystaniem różnych serwisów internetowych, „Roczniki Geomatyki” 2017, t. 15, z. 1(76), s. 97-106.

Sanetra-Szeliga J., Kultura jako element składowy jakości życia w mieście, „Kultura i Rozwój” 2017, nr 1(2), s. 45-59.

Światowy G., Kuźniak K., Miejsce kultury w budowaniu społeczeństwa dobrobytu, „Handel Wewnętrzny” 2017, nr 4(369), s. 425-434.

Ustawa z dnia 25 października 1991 r. o organizowaniu i prowadzeniu działalności kulturalnej (Dz.U. z 2020 r., poz. 194) art. 1 ust. 1, art. 2, art. 11 ust. 2.

Winiarczyk-Raźniak A., Dostepność do usług kulturalnych w Meksyku, „Prace Komisji Geografii Przemysłu PTG” 2009, nr 14, s. 121-129.

Wskaźniki dostępności terytorialnej mieszkańców Polski do wybranych obiektów użyteczności publicznej, GUS, Warszawa 2018.

Zasina J., Wróblewski W., Piesza dostępność udogodnień a struktura przestrzenna starzejącego się miasta, „Studia Ekonomiczne Regionu Łódzkiego” 2016, nr 21, s. $165-176$.

\section{Źródla internetowe}

http://www.gugik.gov.pl/pzgik/zamow-dane/baza-danych-obiektow-topograficznych-bdot-10k [dostęp: 15.03.2020].

http://www.powiatzdunskowolski.pl/ [dostęp: 15.03.2020].

https://bdl.stat.gov.pl/BDL/dane/teryt/tablica [dostęp: 15.03.2020].

https://cargotabor.pl/o-firmie/mapa.html\# [dostęp: 15.03.2020].

https://download.geofabrik.de/europe/poland.html [dostęp: 15.03.2020].

https://mapy.geoportal.gov.pl/wss/service/pub/guest/G2_SKOROWIDZE_BDOT/MapServer/WMSServer [dostęp: 15.03.2020].

https://stat.gov.pl/metainformacje/slownik-pojec/pojecia-stosowane-w-statystyce-publicznej/128,pojecie.html [dostęp: 15.03.2020].

https://www.nck.pl/szkolenia-i-rozwoj/projekty/kultura-sie-liczy-/zarzadzanie-kultura/ dzialalnosc-kulturalna [dostęp: 15.03.2020].

[Artykuł wpłynął: kwiecień 2020; akceptacja: czerwiec 2020] 


\title{
ACCESSIBILITY OF SELECTED CULTURAL INSTITUTIONS IN THE DISTRICT OF ZDUŃSKA WOLA
}

\begin{abstract}
Summary
The aim of this article is to evaluate the accessibility of foot, by bicycle and by car of twenty nine cultural institutions in the district of Zduńska Wola. The research enabled the presentation of detached and multi-family houses inhabitants within isochrones: to $5 \mathrm{mi}-$ nutes, from above 5 to 10 minutes and from above 10 to 15 minutes from the cultural institutions. To achieve this purpose, data from the OpenStreetMap resource, data from the Local Data Bank and the WMS network service, which presents the current Topographic Objects Data Base were used. The analyses indicate that the libraries are characterised by the best accessibility and the museumsare characterised by the worst accessibility. The diversity of inhabitants of this district accessibility to the cultural centres, museums and libraries results from the number and location of individual types of cultural institutions and the distribution ofdetached and multi-family houses. The inhabitants of Zduńska Wola have the best access to the cultural institutions, because the biggest concentrations of multi-family houses and the densest road network in the district of Zduńska Wola occur in this town.
\end{abstract}

Keywords: culture, museums, libraries, Zduńska Wola district, transport accessibility 